University of Missouri-Kansas City School of Law

UMKC School of Law Institutional Repository

2009

Thinking Like a Research Expert: Schemata for Teaching Complex Problem-Solving Skills

Paul D. Callister

Follow this and additional works at: https://irlaw.umkc.edu/faculty_works

Part of the Law Commons 


\title{
Thinking like a Research Expert: Schemata for Teaching Complex Problem-Solving Skills
}

\author{
Paul D. Callister*
}

\section{"We do not first see, and then define, We define first, and then see."-Walter Lippman ${ }^{1}$}

One critical difference between experts and novices as they approach problems is that “[E]xperts notice features and meaningful patterns of information that are not noticed by novices. ${ }^{2}$ Experts see what novices do not, both in the problem, and in the resources available. The knowledge of experts is also highly organized and easily retrievable for application. ${ }^{3}$ Schemata are the key to expert problem solving. Schemata are "organized representations of things or events that guide a person's thoughts and actions." ${ }^{4}$

* Director of the Leon E. Bloch Law Library and Associate Professor of Law, University of MissouriKansas City. B.A., Brigham Young University, 1988; J.D., Cornell Law School, 1991; M.S.L.I.S., University of Illinois at Urbana-Champaign, 2000. The author wishes to thank Barbara Bintliff and Duncan Alford for their encouragement, comments and editing.

${ }^{1}$ WALter LiPPMANN, PUBLIC OPINION 81 (7th printing, 1961).

${ }^{2}$ Commission on Behavioral and Social Sciences and Education, How People Learn: Brain, MIND, EXPERIENCE, AND SCHOOL 19 (1999), available at http://books.nap.edu/openbook.php?record_id=9853\&page=29.

${ }^{3}$ Id. (note items 2 and 4).

${ }^{4}$ See Types of Thinking: Expert and Novice Thinking, ENCYCLOPÆDIA BRITANNICA ONLINE, http://www.search.eb.com/eb/article-275929 (last visited 22 Jan. 2009). Throughout this paper, I use the term the technical term “schemata,” or “schema” for the singular, but I mean it in the broadest sense to include mental constructs, conceptual frameworks, paradigms, and heuristics. 
For law students to acquire complex problem-solving skills, they must build schemata sufficient to the task. This paper illustrates the relationship of schemata to problem solving and presents a complex problem with a succession of schemata necessary for its resolution.

\section{Problem-Solving Schemata}

To illustrate how schemata help solve problems, consider the task of finding Ursa Major, a constellation in the night sky.

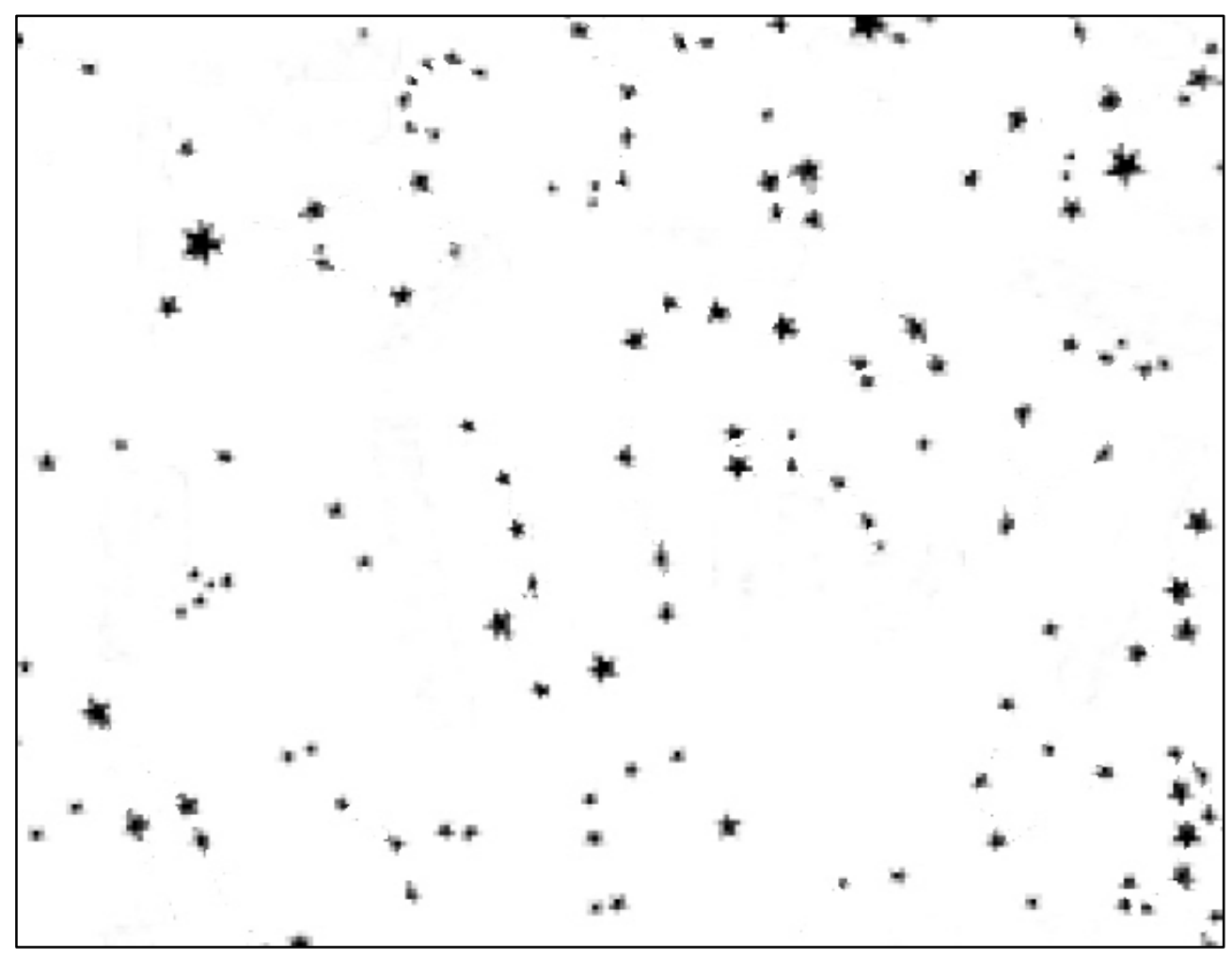

Figure 1 - Find Ursa Major in Night Sky

The task becomes easier once we know that Ursa Major is the "Big Dipper." 


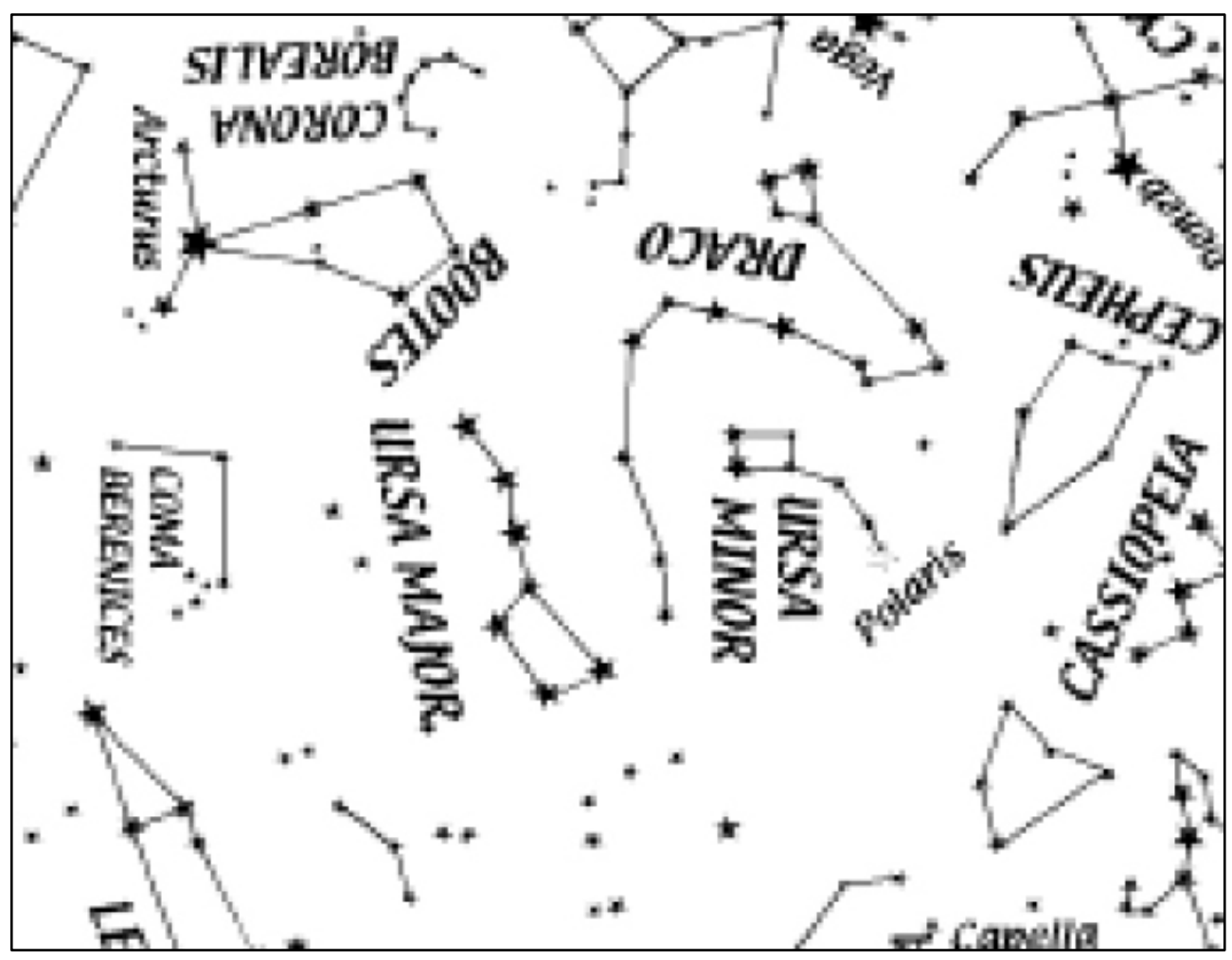

Figure 2-Find the "Big Dipper" in the Night Sky

The same is true of Draco, Ursa Minor and other constellations. We cannot navigate the night sky without these schemata.

The problem for law librarians as instructors of legal research is that we forget what it is like not to know the schemata-what it is like not to be able see Ursa Major as the Big Dipper. There is no going back. The challenge is to find what is implicit in expert legal research that needs to be made explicit. To this end, the definition of schemata, such as the outline of the Big Dipper, is essential to making the invisible visible to our students. As noted above, "We do not first see, and then define. We define first, and then see.”5

\section{A Complex Problem}

\footnotetext{
${ }^{5}$ LIPPMANN, supra note 1.
} 
To illustrate the importance of schemata, consider a complex problem-the kind that makes students respond with a "deer in the headlights" expression and that leads to a lot of “wheel spinning.”

Your firm has been asked to advise $O$.J. Simpson over whether his creditors can seize assets in his profit-sharing plan. During his football career, $O$.J. set up a profit-sharing plan, sponsored by a corporation, for his commercial endorsements. The plan is funded with over four million dollars. O.J. is the sole shareholder of the corporation and only participant in the plan. A senior partner informs you that the federal statute, ERISA, generally protects profit-sharing plans from the reach of creditors. However, since 0 .J. was the sole shareholder of his corporation, the plan is not deemed to have any employees, and consequently it does not fall under ERISA's exemption provisions.

You have been asked to find out if, after 1990, any California court has applied exemptions under California state law to protect a profit-sharing or other retirement plans like $O . J$.'s from the reach of creditors. Even though O.J. prefers not to file for bankruptcy, you are instructed to search the Federal Bankruptcy and Ninth-Circuit courts, since sometimes exemptions under California law are applied (and interpreted by federal courts) in bankruptcy. See 11 U.S.C. $\$ 522($ b).

Figure 3-Find the Key Terms

Although carefully stated, using terms of art, this is a challenging problem, similar to what I sometimes dealt with in practice. In the hypothetical, the problem has been stated by a senior attorney who knows a lot about pension plans, so the researcher has the advantage of technical vocabulary being used "from the get go.” Also the senior attorney has a fairly clear idea of what she wants; if the associate will just pay attention, a number of important clues present themselves.

\section{Schemata for Seeing the Problem}




\section{Apollo 13 and "Working the Problem"6}

"Houston, we have a problem" harbingered one of the most important rescues of the last century—-the near-fatal disaster aboard Apollo 13. In the movie, Apollo 13, NASA flight director Gene Krantz must bring order to the scientists and engineers in the Houston Flight Center, who are reacting to a flood of negative information about Apollo 13. ${ }^{7}$ As portrayed by Ed Harris, Gene Krantz demands that his staff "work the problem” and avoid simply guessing.

The Apollo 13 crisis parallels the initial reaction of new attorneys and law clerks when presented with legal research problems. Reacting to panic, the researcher trips over herself in an effort to foresee an immediate solution. The important lesson to draw from Apollo 13 is to work the problem, not the solution. To do that, the researcher must first find out everything there is to know about the problem. After this initial step, she can match the problem to appropriate strategies and resources for an expedient solution.

\section{Back to Middle School English -Who, What, Where, When, Why and How}

"Working the problem" is something like learning to conduct a good reference interview or completing a writing assignment in middle school. A heuristic model, such as a checklist, can be helpful, but the most important task is to think through the problem and learn as much about it as possible. Medical doctors are taught to do this; vital signs are called out as a patient is wheeled into an emergency room. Law students must also be taught this skill.

The following table breaks down the analytic elements of a typical research problem a new attorney may encounter as part of client interview or as part of an assignment from a

\footnotetext{
${ }^{6}$ Parts of this section initially appeared in Paul D. Callister, Working the Problem, 91 ILL. B.J., Jan. 2003,
} at 43,43 .

\footnotetext{
${ }^{7}$ ApOLLO 13 (Universal Pictures 1995).
} 
supervising attorney. For librarians, this may be recognizable as a reference interview, adapted for use in a law firm setting.

Table 1—“Working the Problem” Schema

\begin{tabular}{|c|c|}
\hline $\begin{array}{l}\text { What You Need to } \\
\text { Know }\end{array}$ & Sample Questions \\
\hline \multicolumn{2}{|r|}{ Who? } \\
\hline Parties & $\begin{array}{l}\text { Who are we representing (i.e., which side of the issue are we on-buyer or seller, } \\
\text { plaintiff or defendant, etc.)? What legal entities are involved (any trusts, } \\
\text { corporations, partnerships, etc.)? }\end{array}$ \\
\hline \multicolumn{2}{|r|}{ What? } \\
\hline $\begin{array}{l}\text { Descriptive Words of } \\
\text { Facts or Terms of Art }\end{array}$ & $\begin{array}{l}\text { Besides the term "profit-sharing plan," are there other terms I should be using, like } \\
\text { "pension" or "retirement"? I'm not sure if I understand the difference or if it } \\
\text { matters. How else might a "sole shareholder" be described in the literature? }\end{array}$ \\
\hline $\begin{array}{l}\text { Descriptive Words of } \\
\text { Legal Issues }\end{array}$ & $\begin{array}{l}\text { Do you think that the best subject heading to describe the problem is "exemptions } \\
\text { from creditors"? }\end{array}$ \\
\hline $\begin{array}{l}\text { Specific Sources to be } \\
\text { Used }\end{array}$ & $\begin{array}{l}\text { For my research on retirement plans and exemptions from creditors, is there any } \\
\text { specific treatise or loose-leaf service I should consult in addition to CCH's } \\
\text { Pension Plan Guide? }\end{array}$ \\
\hline \multicolumn{2}{|r|}{ Where? } \\
\hline Applicable Jurisdictions & $\begin{array}{l}\text { Do you want me to research federal bankruptcy law as well as California debtor- } \\
\text { creditor law? Do you want me to confine my federal research to California? Are } \\
\text { you interested in any other states? Are there any choice-of-law issues? }\end{array}$ \\
\hline \multicolumn{2}{|r|}{ When? } \\
\hline Time Periods & $\begin{array}{l}\text { What time periods do you want me to research? Are the last two years sufficient? } \\
\text { Does the time period (day, night, season, etc.) of any of the events in the case } \\
\text { matter? }\end{array}$ \\
\hline Time Deadlines/Priority & $\begin{array}{l}\text { Do you want a quick answer or exhaustive research? If I complete this by Tuesday } \\
\text { morning, is that ok? }\end{array}$ \\
\hline \multicolumn{2}{|r|}{ Why? } \\
\hline Objective & $\begin{array}{l}\text { What are we trying to accomplish with this memo, brief, motion, contract, etc.? } \\
\text { How do we want this to come out? }\end{array}$ \\
\hline
\end{tabular}




\section{How?}

\begin{tabular}{|c|l|}
\hline Precision/Recall & $\mathbf{8}$ \\
\hline Billable Time/Costs & $\begin{array}{l}\text { Do you want all of the relevant journal articles or just the best article on the topic? } \\
\text { Do you want all of the cases dealing with retirement plans in debtor-creditor law } \\
\text { or just two or three cases that bear the closest relationship to the issue? }\end{array}$ \\
\hline $\begin{array}{c}\text { How long should this take me? Are billable hours limited? May I use LEXIS } \\
\text { and/or Westlaw? Which parts of the research, if any, would you do online? Do } \\
\text { you want me to try and use free sources for my research? Has anyone ever done } \\
\text { similar research on the topic that I should know about? }\end{array}$ \\
\hline $\begin{array}{c}\text { Presentations of Results } \\
\text { and Reporting Back }\end{array}$ & $\begin{array}{l}\text { How do you want me to present my results? Do you just want printouts marked } \\
\text { with highlighter or a full memo? Should I check back with my initial results } \\
\text { before proceeding any further? }\end{array}$ \\
\hline
\end{tabular}

Considering the O.J. Simpson hypothetical in Figure 3, the task is to extract the terms that will lead to an understanding of the issue, and ultimately the answer and relevant authority on the issue.

${ }^{8}$ Precision is a ratio relevant documents expressed as:

$$
\left(\frac{\text { Number of Relevant Documents Retrieved }}{\text { Total Number of Documents Retrieved }}\right) \times 100
$$

Recall is defined:

$$
\left(\frac{\text { Number of Relevant Documents Retrieved }}{\text { Total Number of Relevant Documents in the Collection }}\right) \times 100
$$

F. W. Lancaster, Precision and Recall, 2 ENCYCLOPEDIA OF LIBRARY AND INFORMATION SCIENCE 2346, 2346

(Marcia J. Bates, Mary Niles Maack \& Miriam Drake eds., 2nd ed. 2003). 


\section{Term of art; entity involved Who? The entity being represented}

Body of law

red herring

since ERISA

Your firm has been ash $d$ to advise O.J. Simpson over whether his creditors can Distinguishing seize assets in his profit-sharing plan. During his football career, O.J. set up a profit-sharing plan, sponsored by a corporation for his commercial endorsements.

The plais is funded with over four million dollars. O.J. is the sole shareholder of ine corporatior and only participant in the plan. A senior partner informs you that the federal statute, ERISA, generally protects profit-sharing plans from the reach of creditors. However, since O.J. was the sole shareholder of his corporation, the plan is not deemed to have any employees, and consequently it does not fall under ERISA's exemption provisions.

Y 6 u have been asked to find out if, after 1990, any California court has applied exemptions under California state law to protect a profit-sharing or other retirement plans like O.J.'s from the reach of creditors. Even though O.J. prefers not to file for bankruptcy, you are instructed to search ine Federal Bankruptcy and Ninth-Circuit courts. since sumetmes exemptions under California law are applied (and interpreted by federal court:; is bankruptey. See 11 L.S.C. § $522($ b).

Figure 4-Illustration of Key Terms

In the problem, the general subject area is the intersection of qualified retirement plans (or "profit-sharing plans") and debtor-creditor law. A possible start would be to use some index to either lookup “creditor" under "profit-sharing plans” or inversely, "profit-sharing” under “creditor.” The issue involves the subject of "exemptions,” which is generally a sub-topic of debtor-creditor law. The narrow issue is the application of exceptions to "single person plans," which is a term of art used by practitioners, but often not found in indexes. If no such entry exists, or a search for items using such terms bears no fruit, then I would search using combinations of "sole," "single," and "only" with "shareholder" and "stockholder." Finally, the research should only concern cases after 1990 in California state courts and in the Ninth Circuit (but limited to California cases).

\section{What Kind of Problem is it?}

In library school, I had a marvelous teacher who gave me a schema for looking at types

of problems related to government documents. While I immediately realized that the table could be readily adapted for legal research, the greater revelation was that while not all problems were 
alike, they could be grouped into types, with certain types of problems requiring specific, yet different, strategies and resources for resolution. For instance, one of my first research problems in practice was, "What is the average age of retirement of female OB/GYN physicians in the Los Angeles area?” I was totally unnerved by the problem because it was of a type I had never encountered. Fundamentally, statistical problems require different strategies and resources to solve than questions about the rule against perpetuities in North Dakota. 
Below is the table developed by my former Government Documents instructor from library school, which I have modified for legal research. ${ }^{9}$

Table 2-Problem Typing

\begin{tabular}{|c|l|l|}
\hline Search Type & \multicolumn{1}{|c|}{ Used For } & \multicolumn{1}{|c|}{ Example } \\
\hline Known Item & $\begin{array}{l}\text { You already know the citation, case name, name of an act, or } \\
\text { have a very specific fact pattern to research. }\end{array}$ & $\begin{array}{l}\text { I need Roe v. Wade. } \\
\text { I need any California or Ninth Circuit case involving exemptions from } \\
\text { creditors and the debtor's interest in a retirement plan that falls outside of } \\
\text { ERISA's anti-alienation provisions because it is sponsored by a } \\
\text { corporation with one shareholder and no employees other than the } \\
\text { shareholder. }\end{array}$ \\
\hline Subject & $\begin{array}{l}\text { You are not looking for a specific item but for information on } \\
\text { a particular subject. }\end{array}$ & $\begin{array}{l}\text { I am looking for something explaining ERISA generally, including what } \\
\text { kind of retirement plans it covers. } \\
\text { I need to understand exemptions from creditors in California. }\end{array}$ \\
\hline Institutional & $\begin{array}{l}\text { You know what you are looking for will be found at a } \\
\text { particular institution, agency, or organization, or you want to } \\
\text { find out what agency administers a particular program or } \\
\text { enforces a particular law. }\end{array}$ & $\begin{array}{l}\text { I need Department of Justice Rulings and Opinion Letters on when the } \\
\text { forger of two large medical groups falls within the safe harbor provisions } \\
\text { I need any Department of Labor rulings regarding the “anti-alienation” } \\
\text { provisions of ERISA. }\end{array}$ \\
\hline Statistical & $\begin{array}{l}\text { You need statistical information from a government or other } \\
\text { trustworthy source. }\end{array}$ & $\begin{array}{l}\text { I need to know the percentage of children living below the poverty level in } \\
\text { Los Angeles. }\end{array}$ \\
\hline
\end{tabular}

${ }^{9}$ For the original schema, as used with government documents, see JEAN L. SEARS \& MARILYN K. MOODY, Using GovernMENT INFORMATION SOURCES: ELECTRONIC AND PRINT 5-9 (3rd ed. 2001). 


\begin{tabular}{|c|l|l|}
\hline Search Type & \multicolumn{1}{|c|}{ Used For } & \multicolumn{1}{c|}{ Example } \\
\hline $\begin{array}{c}\text { Special } \\
\text { Techniques }\end{array}$ & $\begin{array}{l}\text { You are searching for materials that require special } \\
\text { interpretive or inter-disciplinary skills. }\end{array}$ & $\begin{array}{l}\text { I need legislative history and current legislation and regulatory action; } \\
\text { budget, patent, census, and historical materials; government documents; } \\
\text { international and foreign law; tax forms and IRS materials; scientific and } \\
\text { technical reports; public records; or competitive business intelligence. } \\
\text { I need the legislative history of the ERISA anti-alienation provisions. }\end{array}$ \\
\hline News & You are searching for news stories. & $\begin{array}{l}\text { I need accounts of the lawsuit in France by a humanitarian group against } \\
\text { Yahoo. }\end{array}$ \\
\hline Reference & You need basic background or definitional information. & $\begin{array}{l}\text { I need to know the etymology of "escrow." } \\
\text { I don't even know what "ERISA” is. }\end{array}$ \\
\hline
\end{tabular}


Returning to the O.J. Simpson problem in Figure 3, even after having "worked" the problem with a "who, what, why, where, when, how" analysis, the researcher is not ready to start until she has figured out what kind of problem or problems she has on her hands. However, before suggesting problem types and matching them to resources, we need to map the terrain of resources.

\section{Schemata for Understanding Resources-Conceptually Mapping the Terrain of Legal Resources}

Like problem types, legal resources fall into different classes that can be organized in different ways. Two of the most common ways of arranging them are based on the distinction between primary and secondary, and by chronology, subject, and citation.

\section{Mapping Primary and Secondary Resources}

Hopefully, students learn the distinction between primary and secondary resources during their first year. Because of the heavy focus during the first year on official or "flagship" primary resources (like the U.S.C. and U.S.C.A.), what is often more difficult to grasp is the appropriate use of combined primary and secondary resources. The following table illustrates a schema to help students arrange or map resources in relation to primary and secondary authority and their respective uses.Table 3-Primary and Secondary Authority

\begin{tabular}{l|l|l|l}
\hline \multicolumn{1}{|c|}{ General Examples } & & \multicolumn{1}{|c}{ Binding Upon } \\
source & & All branches of government. \\
\hline & Constitutions & Except as found unconstitutional, all branches of government. \\
\hline
\end{tabular}




\begin{tabular}{|c|c|c|c|}
\hline & General Examples & Binding Upon & Used For \\
\hline & $\begin{array}{l}\text { Court Decision Reporters, Case Digests and } \\
\text { WORDS AND PHRASES }(1940-)^{10}\end{array}$ & $\begin{array}{l}\text { Binding upon lower courts of the same jurisdiction and other } \\
\text { branches of government. }\end{array}$ & \multirow[t]{3}{*}{ authority. } \\
\hline \multicolumn{2}{|r|}{$\begin{array}{l}\text { Codified Regulations or Administrative Codes and } \\
\text { Administrative Registers or Regulations }\end{array}$} & $\begin{array}{l}\text { Legislative regulations (i.e., when Congress has delegated } \\
\text { legislative rulemaking to an agency) may be binding upon the } \\
\text { issuing agency and the general public. } \\
\text { Interpretive regulations (i.e., issued to provide guidance of an } \\
\text { agency's position on an issue or to clear up ambiguity) may hold } \\
\text { an agency and the public bound to a particular interpretation of } \\
\text { legislation to the extent courts do not disagree. }\end{array}$ & \\
\hline & Administrative Agency Opinions and Rulings & $\begin{array}{l}\text { Generally binding upon the agency. Sometimes, may only be } \\
\text { binding upon the agency with respect to the parties in question. }\end{array}$ & \\
\hline
\end{tabular}

${ }^{10}$ The placement of case digests and Words and Phrases as primary materials may seem odd given their topical arrangement as indexes, but the idea is that they provide a subject arrangement of case summaries granting access directly to the case reporters without intervening commentary. 


\begin{tabular}{|c|c|c|c|}
\hline $\begin{array}{l}\text { ye of } \\
\text { source }\end{array}$ & General Examples & Binding Upon & Used For \\
\hline 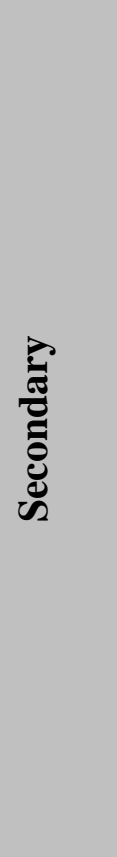 & $\begin{array}{l}\text { Encyclopedias (e.g., AMERICAN JURISPRUDENCE } \\
\text { (2nd ed. 1961-)) } \\
\text { Treatises and Hornbooks (e.g. RONALD D. } \\
\text { ROTUNDA \& JOHN E. NOWAK, TREATISE ON } \\
\text { CONSTITUTIONAL LAW: SUBSTANCE AND } \\
\text { PROCEDURE (4th ed. 2007) and DAVID G. OWEN, } \\
\text { PRODUCTS LIABILITY LAW (2nd ed. 2008)) } \\
\text { Law Reviews (e.g., articles reviewing particular } \\
\text { areas of the law, such as Meredith L. Taylor, North } \\
\text { Carolina's Recognition of Tort Liability for the } \\
\text { Intentional Infliction of Emotional Distress During } \\
\text { Marriage, 32 WAKE FOREST LAW REVIEW } \\
\text { 1261(1997)) } \\
\text { Professional \& Bar Journals (e.g., Paul D. Callister, } \\
\text { Charitable Remainder Trusts: An Overview, 51 } \\
\text { TAX LAWYER 549 (1998)) } \\
\text { Form Books (e.g., JACOB RABKIN AND MARK H. } \\
\text { JOHNSON, CURRENT LEGAL FORMS, WITH TAX } \\
\text { ANALYSIS (1948-)) }\end{array}$ & Not binding. & $\begin{array}{l}\text { Subject, statistical and } \\
\text { special experience } \\
\text { searches where you need } \\
\text { to understand the issues } \\
\text { and background of an } \\
\text { area of law or problem. } \\
\text { Also use to confirm your } \\
\text { interpretation of a } \\
\text { primary source. }\end{array}$ \\
\hline 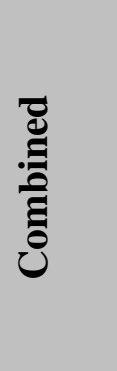 & $\begin{array}{l}\text { Loose-leafs (e.g., CCH STANDARD FEDERAL TAX } \\
\text { REPORTER (1913-)) } \\
\text { News Services (e.g., BNA, U.S. LAW WEEK (1933- } \\
\text { )) } \\
\text { AMERICAN LAW REPORTS (6th ed. 2006) }\end{array}$ & Only primary sources have any binding authority. & $\begin{array}{l}\text { Use when ease is } \\
\text { important. Loose-leafs } \\
\text { combine statutes, } \\
\text { regulations, commentary, } \\
\text { and case law annotations } \\
\text { in a topical arrangement } \\
\text { with a good table of } \\
\text { contents and indexing } \\
\text { system. }\end{array}$ \\
\hline
\end{tabular}


As a practicing attorney for nine years in the areas of tax, retirement plans, transactional law and estate planning, combined resources of primary and secondary materials, such as the CCH Standard Federal Tax Reporter, dominated my research. The ability to jump between the IRS code, regulations, commentary and annotations was essential to understanding the law and efficiently researching complex problems. I suspect that for many attorneys, regardless of their area of expertise, secondary and combined resources dominate their research. Most questions are of a subject type, and so secondary and combined resources become more important than the use of the primary materials, which are often emphasized in first year Legal Research and Writing.

\section{The Wren Matrix}

In 1986, Christopher G. Wren and Jill Robinson Wren introduced a matrix showing how all three branches of government had reporters or codes that were published in both chronological and topical formats. ${ }^{11}$ Below is the table illustrating the Wrens' schema, but adding a new column for arrangements based upon citation.

Table 4-Arrangement of Primary Sources

\begin{tabular}{|c|c|c|c|c|}
\hline \multirow{2}{*}{ Institution } & \multirow{2}{*}{$\begin{array}{l}\text { Kind of } \\
\text { Law }\end{array}$} & \multicolumn{3}{|c|}{ How the Law is Published (Arrangements) } \\
\hline & & $\begin{array}{l}\text { Chrono- } \\
\text { logically }\end{array}$ & Topically & By Citation \\
\hline Legislature & $\begin{array}{l}\text { Statutory } \\
\text { Law }\end{array}$ & Session Laws & Statutory Codes & $\begin{array}{l}\text { Shepard's, KeyCite, Annotated } \\
\text { Codes }\end{array}$ \\
\hline
\end{tabular}

${ }^{11}$ See Christopher G. Wren \& Jill Robinson Wren, The Legal Research Manual: A Game Plan FOR LEgAL ReSEARCH AND ANALYsis 6 (2nd ed. 1986) and Christopher G. Wren \& Jill Robinson Wren, The Teaching of Legal Research, 80 LAW LiBR. J. 7, 35 matrix A (1988). 


\begin{tabular}{|c|c|c|c|c|}
\hline Courts & Case Law & Case Reports & $\begin{array}{l}\text { Case Digests } \\
\text { (Summaries of } \\
\text { Primary } \\
\text { Authority) }\end{array}$ & Shepard's, KeyCite, ALR \\
\hline $\begin{array}{l}\text { Agencies and } \\
\text { Executive } \\
\text { Branch }\end{array}$ & $\begin{array}{l}\text { Admin- } \\
\text { istrative } \\
\text { Law }\end{array}$ & $\begin{array}{l}\text { Administrative } \\
\text { Registers or } \\
\text { Regulations }\end{array}$ & $\begin{array}{l}\text { Administrative } \\
\text { Codes }\end{array}$ & $\begin{array}{l}\text { Shepard's, KeyCite, Annotated } \\
\text { Codes }\end{array}$ \\
\hline
\end{tabular}

Going beyond the Wren's schema, I have added a column suggesting that the law is also organized by citations. Shepard's, Key Cite, code annotations, and ALR organize the law into “streams of precedent," ${ }^{212}$ for cases, and place codes within the context of their interpretation by courts and other statutes or regulatory materials. They allow researchers to see the law, not as a single case or statute, but as it evolves through time and interacts with other law around it. A former colleague of mine, Peter Hook, once suggested that the table could also be expanded to add a column for the "making” of the law: legislative history documents, briefs, tables of authority, ${ }^{13}$ hearing transcripts, motions, and pleadings, regulatory rulemaking and agency decisions, executive orders, etc. Conspicuously missing from the arrangement is a row for constitutions and corresponding documents. Furthermore, international treaties and conventions might also be added as a row to the table. The point is to start with a simple schema and add on new resources and explain where they would fit. For example, the Digest of Decisions of the

\footnotetext{
${ }^{12}$ For a schemata illustrating precedent in the stream of time, see infra Figure 9 and accompanying text.

${ }^{13}$ By "tables of authority” (sometimes “points of authority”), I mean the sources cited in a case that,
} together with that case and subsequent cases, make up the "stream of precedent.” Tables of authority can be accessed in the Shepard's and KeyCite features of Lexis and West's online services, respectively. See Figure 9 below and accompanying text. 
Federal Labor Relations Authority comes from the administrative branch and is topically arranged; it would find its place in the box with administrative codes. ${ }^{14}$

\section{Intermediation v. Disintermediation-The Final Dimension of Legal Research}

Having divided the universe of resources into primary versus secondary and

chronological versus topical arrangements, it is time to introduce the distinction that has profoundly impacted legal research-print versus electronic-and promptly denounce it as an inadequate distinction for failing to address the more important phenomenon of disintermediation and the collapse of hierarchical authority. A better way to describe the dichotomy is between human-intermediated indexes and disintermediated computer algorithms, such as free-text searching (whether incorporating Boolean terms and connectors or relevancyranked natural language algorithms). ${ }^{15}$ Google and Yahoo! illustrate this distinction. Google’s

${ }^{14}$ See OfFice of InFormation Resources AND RESEARCh SERVICES, Digest OF DECISIONS OF THE FEDERAL LABOR RELATIONS AUTHORITy (1989-).

${ }^{15}$ Both term-and-connector searching and relevancy-ranked natural language searching, each of which is offered by Lexis and Westlaw, operate by computer algorithm. In the case of the former, the search interface responds to specific commands (such as "w/5" or "and”) to construct its database search. "Terms and connectors" searching includes Boolean search commands such as “and,” "or” and "not.” In contrast, relevancy-ranked natural language searching involves a computer algorithm which "resorts" the database with the most relevant documents “on top.” The algorithm may favor documents with search terms that are proximate to each other, in certain fields, or which appear multiple times in the same document. The exact operation of a relevancy-ranked natural language algorithm is proprietary and usually not disclosed. See Danny C.C. Poo \& Christopher S.G. Khoo, Online Catalog Subject Searching, in 2 ENCYCLOPEDIA OF LIBRARY AND INFORMATION SCIENCE 2218, 2224 (2003) (description of relevancy-ranked natural language searching); Paul D. Callister, Introduction to Online Legal Research, Westlaw: Natural language Searches, at http://www1.law.umkc.edu/faculty/callister/bootcamp/ot/NL01.html (last visited Nov. 
natural language search mechanism works through a computer algorithm producing relevancyranked search results. In contrast, Yahoo! (which stands for "Yet Another Hierarchical Officious Oracle”) ${ }^{16}$ finds information based upon an hierarchical taxonomy classifying links intermediated by human beings. Web site operators submit links to Yahoo! Directory with category suggestions and Yahoo! editors review the submission before linking the suggested site into the Yahoo! hierarchy. ${ }^{17}$ Other current web examples of intermediated systems are Wikipedia ${ }^{18}$ and Delicious, ${ }^{19}$ where users vet and submit entries. In some ways these systems might be described as user-mediated, rather than expert-intermediated (although the relative expertise of the content contributors of such systems is open to debate). ${ }^{20}$

26, 2008) (archived version of Westlaw and Lexis online services tutorial initially prepared for the University of Illinois College of Law in 2002).

${ }^{16}$ Yahoo! Press Room: FAQ, at http://yhoo.client.shareholder.com/press/faq.cfm (follow link to "What does Yahoo! Stand for?”) (last visited Sept. 12, 2008). Google’s name plays upon the mathematical term, "googol” meaning 1 with a hundred zeros after it. Google: Corporate Information, at http://www.google.com/intl/en/corporate (last visited Jan. 26, 2009).

${ }^{17}$ See Yahoo! Directory Suggest a Site, at http://add.yahoo.com/fast/add (last visited Sept. 12, 2008). Students may confuse Yahoo! Directory with its search engine, which is also algorithmic.

${ }^{18}$ Wikipedia, at http://www.wikipedia.org (last visited Jan. 26, 2009).

${ }^{19}$ Delicious Social Bookmarking, at http://delicious.com (last visited Jan. 26, 2009).

${ }^{20} \mathrm{Jim}$ Giles, Internet Encyclopaedias Go Head to Head, 438 NATURE 900 (2005) (reporting study finding 162 factual errors versus 123 such errors in Wikipedia compared to Encyclopaedia Britannica); Paulo N. Correa, Alexandro N. Correa, \& Malgosia Askanas, Wikipedia: A Techno-Cult of Ignorance, at http://www.aetherometry.com/Electronic_Publications/Politics_of_Science/Antiwikipedia/awp_index.html (last visited Nov. 28, 2008). 
The critical distinction for students to understand is between intermediation and disintermediation. In most instances, that distinction aligns with whether the service includes a controlled vocabulary index designed by human beings or whether access is provided via computer search algorithms of full text. Pedagogically, grounding the instruction in the difference between print and electronic promotes an underdeveloped schema for understanding the terrain of resources, and hampers modeling how to match resources to problem types.

\section{Schemata for Matching Problems to Resources Mapping Octants for Known Item and Subject Searches}

In Figure 5 below, the terrain of research resources has been divided into octants. First, quadrants are formed by axes of primary versus secondary authority and chronological versus subject arrangement. Next, octants are formed by dividing the quadrants with the addition of a third axis—-human-mediated controlled vocabulary indexes versus disintermediated computer algorithms. Most resources can be placed into this schema. The shaded areas illustrate the starting points for "known item" and "subject" searches, as previously defined in Table 2 above. I have also posted an interactive schema that gives examples of resources in each of the research octants on the Web. ${ }^{21}$

${ }^{21}$ Paul D. Callister, Thinking About Legal Research Problems, Putting a Search Together, at http://www1.law.umkc.edu/faculty/callister/bootcamp/Survival/tab5.html (last visited Nov. 29, 2008). 


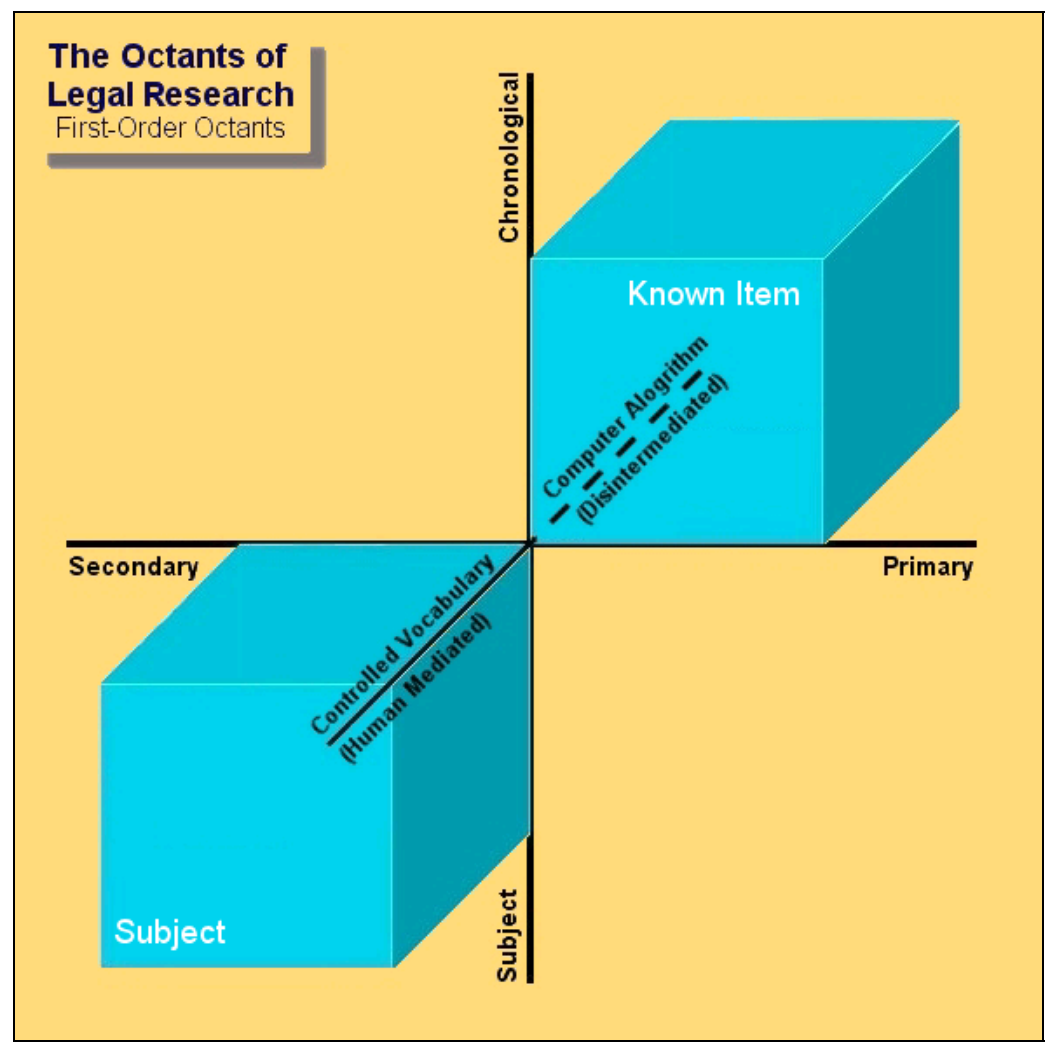

\section{Figure 5-Legal Research Octants}

To illustrate the schema's use, consider the O.J. Simpson problem. The researcher has been asked to find any cases in California courts or in the Ninth Circuit that have applied state law exemptions to prevent creditors from reaching the assets held in profit sharing plans that do not fall under the anti-alienation protections of ERISA (because they have single shareholder owners and, technically, no employees). These facts and issues are very narrow and particular. While the researcher does not know if such a case exists, this research question is a "known item” problem because a case with such a pattern of facts and issues may actually exist, and therefore can be located and "known." If not, the researcher will have to broaden his or her search, including looking for an analogous situation, or move on to a subject search. 
Per the octant schema in Figure 5, the researcher should probably start by searching the CA Federal \& State Cases, Combined on Lexis (or similar database on Westlaw), ${ }^{22}$ which is a primary, chronological and algorithmic resource. A detailed terms and connectors search can be structured using the key terms identified in Figure 4 above:

((Creditor or Debtor) /p Exemption) \& ("Profit Sharing Plan" or "Retirement Plan") \& ((Sole or Single or Only) /2 (Shareholder or Stockholder)) \& (date > 12/31/1990)

In this instance, the Lexis search retrieves eleven cases. Lexis' overview for the first case, In re Stern, reads:

The appellate court found that the district court properly determined that the plan was not ERISA-qualified at the time of the bankruptcy filing and, thus, the plan's assets were not exempt from the bankruptcy estate by virtue of ERISA qualification. But, when the debtor's bankruptcy petition was filed, the assets rested in the plan which enjoyed an exempt status under California law. Also, the mere fact that the debtor converted nonexempt assets into exempt assets was insufficient to prove a fraudulent transfer. Thus, the district court properly held that the transfer of assets from the IRA to the plan was not fraudulent. $^{23}$

${ }^{22}$ For Lexis, see Cases - U.S./Federal \& State Cases By State/ CA Federal \& State Cases, Combined. For Westlaw, see California State and Federal Cases (CA-CS-ALL).

${ }^{23}$ Gill v. Stern (In re Stern), 345 F.3d 1036 (9th Cir. 2003), cert denied, Stern v. Gill, 541 U.S. 936 (U.S. 2004) (quote from the Lexis Case Summary Overview). 
This case is directly on point. Seven other cases of the eleven are also relevant and within the appropriate jurisdictions. ${ }^{24}$ The researcher has quickly found a starting point for further research.

Prior to conducting a known item search for specific cases, the same researcher might feel that she needs some background information on profit-sharing plans, bankruptcy, ${ }^{25}$ debtorcreditor law, and, if available, the intersection of all three (the last of which might be impossible to find). These are subject problem types, and, per the chart in Figure 5, the researcher should use secondary (non-“authoritative”) resources, arranged by subject, intermediated by human indexers or catalogers. For instance, the researcher might go to Aspen’s Pension Answer Book (a handbook with quick answers to pension questions and an overview of pension law), ${ }^{26}$ the multi-

${ }^{24}$ Carter v. Anderson (In re Carter), 182 F.3d 1027 (9th Cir. 1999); In re Cheng, 943 F.2d 1114 (9th Cir. Cal. 1991); In re Smith, 1998 U.S. Dist. LEXIS 22964 (C.D. Cal. 1998), rev’d on other grounds, Smith v. Kennedy (In re Smith), 235 F.3d 472 (9th Cir. Cal. 2000); In re Acosta, 182 B.R. 561 (N.D. Cal. 1994); McDonald v. Metz (Metz), 225 B.R. 173 (B.A.P. 9th Cir. Cal. 1998); Southern Cal. Permanente Med. Group v. Ehrenberg (In re Moses), 215 B.R. 27 (B.A.P. 9th Cir. Cal. 1997; In re Witwer, 148 B.R. 930 (Bankr. C.D. Cal. 1992), aff'd mem. In re Witwer, 163 B.R. 614 (B.A.P. 9th Cir. 1994).

${ }^{25}$ As noted in Figure 4 above, researching federal bankruptcy law is really only necessary for background information: to understand that sometimes bankruptcy and federal appellate courts apply state exemptions under 11 U.S.C $\S 522$ (b), and that any interpretive rulings by such courts on California exemption law may be persuasive authority.

${ }^{26}$ See Stephen J. Krass, The Pension Answer BoOK, ๆ Q 4:26 (2008 ed.) (by searching under "Creditors" in the index, a reference to "qualified retirement plans" can be found, but the discussion in the section is confusing because of the multiple jurisdictions it covers and the fact that it never really gets beyond the issue of whether a plan falls under ERISA and its anti-alienation provisions, or whether the plan was properly qualified by the IRS). 
volume Collier on Bankruptcy, or California Jurisprudence (for background on exemptions under bankruptcy or debtor-creditor law). After perusing the Pension Answer Book, the researcher might go to a combined primary and secondary resource, such as the $\mathrm{CCH}$ Pension Plan Guide, accessing pertinent subjects by the index ("Bankruptcy ... exemptions ... failure to establish a ERISA plan).,27

Because the goal is to learn to use intermediated resources, instructors should not be concerned whether the students use these secondary, subject resources online or in print, provided that the online databases include usable indexes and tables of contents (that can be “drilled down”).

In the above example, orienting the research toward a "subject" problem type does not retrieve resources that have dealt with the specificity required to answer the questions about retirement plans not falling under ERISA, but which still might be exempt from the reach of creditors; however, it does produce some important background for understanding the overall problem. In contrast, a known item search retrieved cases exactly on point. Consequently, understanding methodologies appropriate for each of the problem types is critical to the solution of this complex problem.

What about resources in the other six octants? There are resources that can be placed into each of these quadrants. They have their uses, as will be discussed below, but not in the initial stages of research, with the only exception being for statutory law. Most of the time, the code (a topical arrangement of the law) is cited, rather than the chronological arrangement.

\footnotetext{
${ }^{27} 1$ Pension Plan Guide (CCH) (no paragraph numbering for citing the index, look under "Bankruptcy” in
} the index). 
Consequently, many known item problems referring to a statute may require searching the code, rather than the Statutes at Large or state session laws. On the other hand, sometimes what is presented in the problem is the name of an act, such as ERISA, or a recently enacted bill. Answering this type of problem typically requires access through a "Popular Name" table for statutes (available in print and on Lexis and Westlaw), or on the Web through a free-text search of Thomas (using the name of a recently enacted bills). ${ }^{28}$ Indeed, when codified, the text of many acts are separated and scattered throughout the code, and it is often easiest to read a statute in its chronological form in the Statutes at Large or state session laws.

In sum, the octants schema is really designed to help researchers separate those resources that should be used first from those that will be used later in the research cycle.

\section{The Research Cycle}

The uses of other octants in Figure 5 become more apparent in consideration of the larger research cycle.

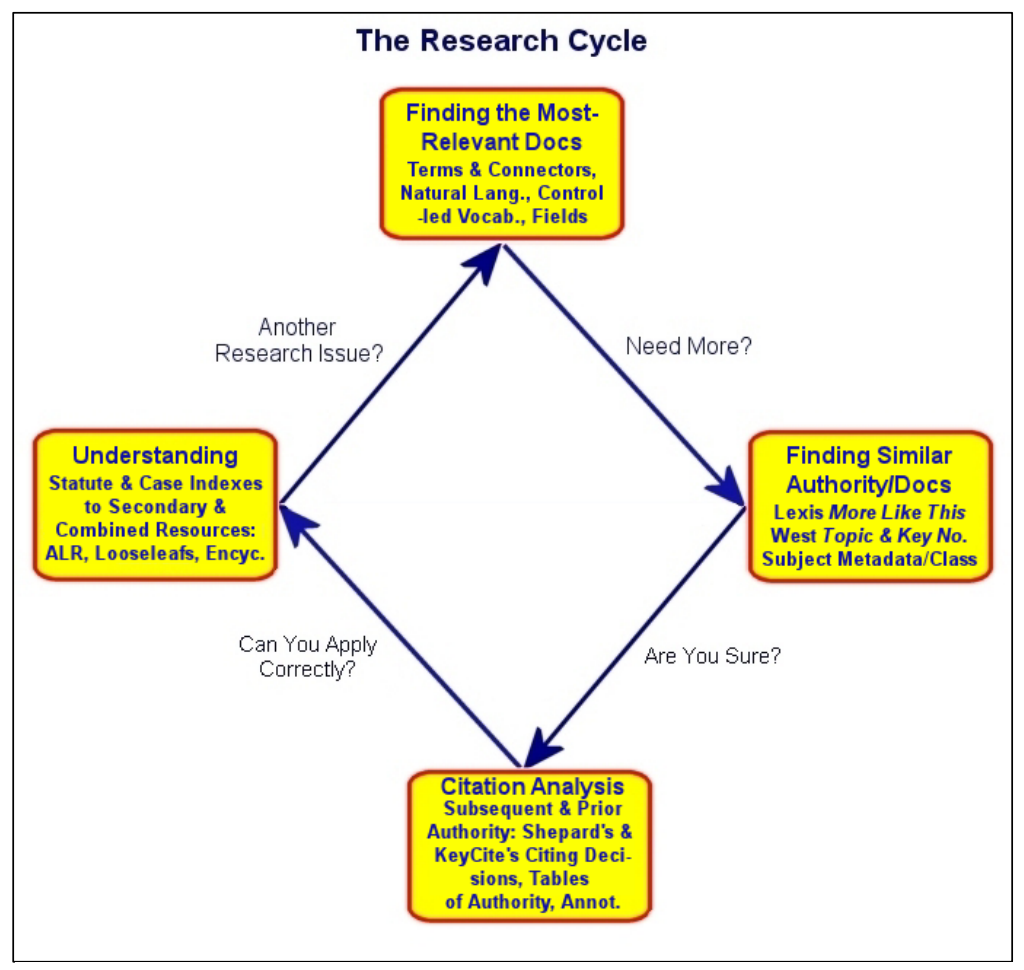

Figure 6-The Research Cycle

\footnotetext{
${ }^{28}$ See Library of Congress, Thomas, at http://thomas.loc.gov (last visited Nov. 29, 2008).
} 


\section{Find the Most Relevant Documents}

In Figure 6, the researcher starts at the top of the schema with "Finding the Most Relevant Documents,” and then proceeds through each of the steps until returning to the beginning, perhaps starting again with a new research issue. The first step in any research project, after "working the problem" and determining its type, is not to find everything on point—a common mistake among the uninitiated—but to find the most relevant document (or documents) on point. By moving quickly and rejecting items, even if tangentially related but not directly on point, the researcher can then go on to finding everything else she needs.

To illustrate "Finding the Most-Relevant Document" in the O.J. Simpson problem, I used a "known item" methodology and constructed a term and connector search, limited by a date field, to attempt to find the most relevant cases on point in the Lexis CA Federal \& State Cases, Combined. ${ }^{29}$ Eight of my eleven cases were on point and within the relevant California and Federal jurisdictions. If I look at Lexis’ Headnote 2 for In Re Cheng, ${ }^{30}$ the fifth case on point, it discusses the application of a specific statute, California Code of Civil Procedure $§ 704.115$, which exempts assets of a profit sharing plan from the reach of creditors in bankruptcy. ${ }^{31}$

\footnotetext{
${ }^{29}$ For search terms, see text accompanying supra note 23.

30 943 F.2d 1114.

31 The reason California’s state exemption statute applies is because under 11 U.S.C. § 522(b) (2000 \&
} Supp. V 2007) the debtor may use exemptions designated by state statutes rather than those provided in the Bankruptcy Code. Pursuant to CAL CIV. Proc. CoDE $§ 703.140$ (Deering 2008), debtors may elect to use any exemption from creditors in the California code’s chapter, including $§$ 704.115, which exempts “[a]ll amounts held, controlled, or in process of distribution” from a profit sharing plan. See id. at (a)(2) and (b). 


\section{Finding Similar Authority}

Next I proceed to the step of the cycle of "Finding Similar Authority"-in this instance, other similar cases. I follow the hyperlink reading “More Like This” on the top navigation bar. ${ }^{32}$ I use the “core terms” suggested by Lexis’ natural language index and run my search in California Federal and State Cases, Combined.

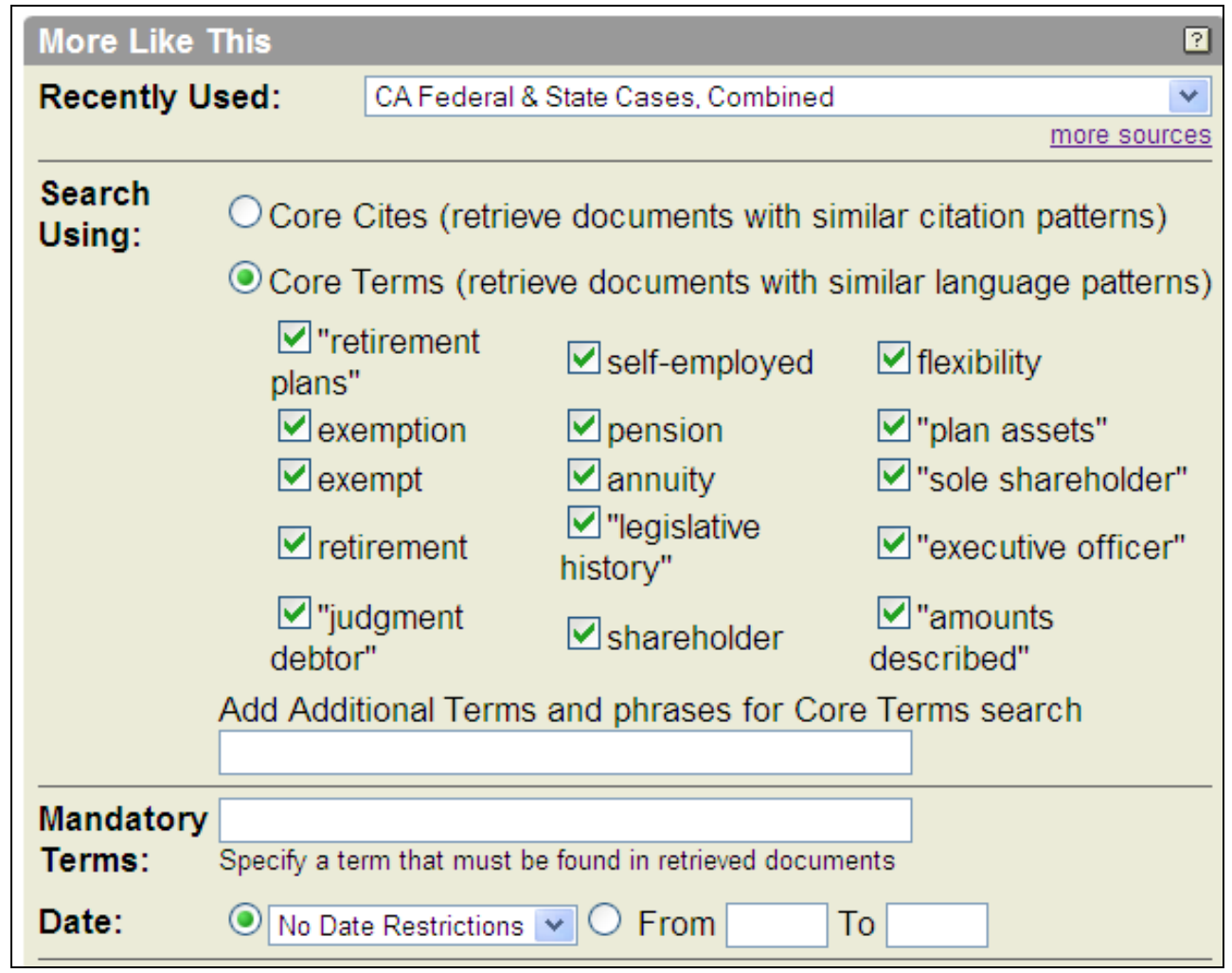

\section{Figure 7-Lexis "More Like This" Search}

The search retrieves one hundred cases because a relevancy ranked algorithm is used, but the most relevant cases should be on top, and indeed, the first case after In Re Chang, which is its

\footnotetext{
${ }^{32}$ In the octant schema, this particular Lexis "More Like This" search is a primary, subject, computer
} algorithm search. 
own best match, is In re Witwer. ${ }^{33}$ In this decision, the Bankruptcy Court exempts profit sharing assets from creditors under the same statute, California Code Civil Procedure § 704.115.

In Westlaw, finding similar cases can be done by searching for similar cases using the headnote, Topic and Key Numbers at the beginning of the decision. By clicking on Key Number 163k49 k (Pension and Retirement Funds and Accounts), I then can run a search in State and Federal Cases, California and find all similar cases as classified by West editors. ${ }^{34}$

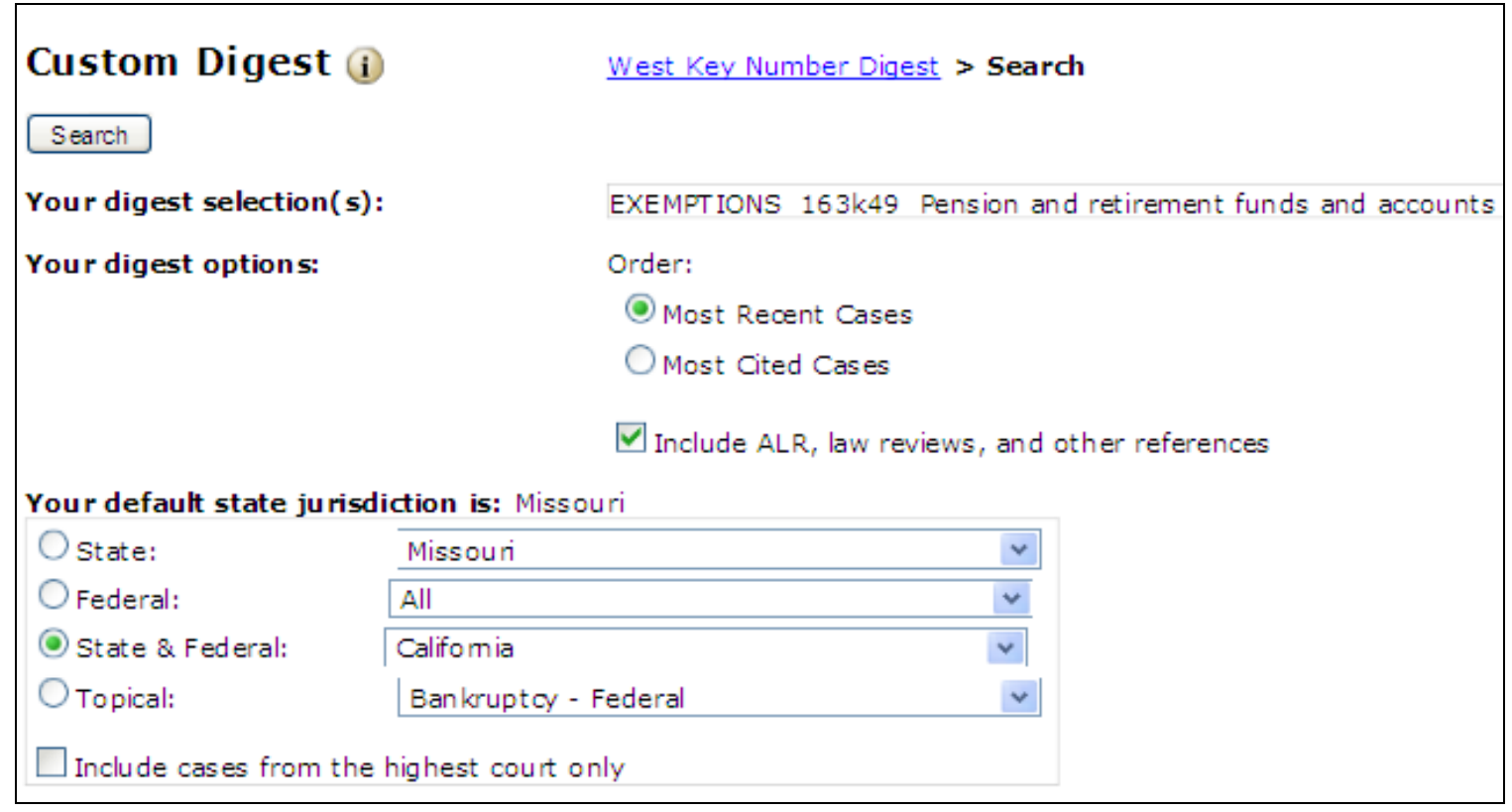

Figure 8-West Key Number Search for Similar Cases

Having found similar cases, it is now time to do citation analysis to check the status of the case law.

\section{Citation Analysis}

${ }^{33}$ In re Witwer, 148 B.R. 930 (Bankr. C.D. Cal. 1992).

${ }^{34}$ Unlike Lexis’ “More Like This” searching, West’s “Topic and Key Number” searching is mediated by human beings, and it would be placed in the primary, subject, human-intermediated octant. 
Citation analysis will also help find other relevant cases. With respect to Lexis and Westlaw, it is important to consider not only subsequent cases and history which may cast doubt on whether the original case

is still good law, but whether the foundation

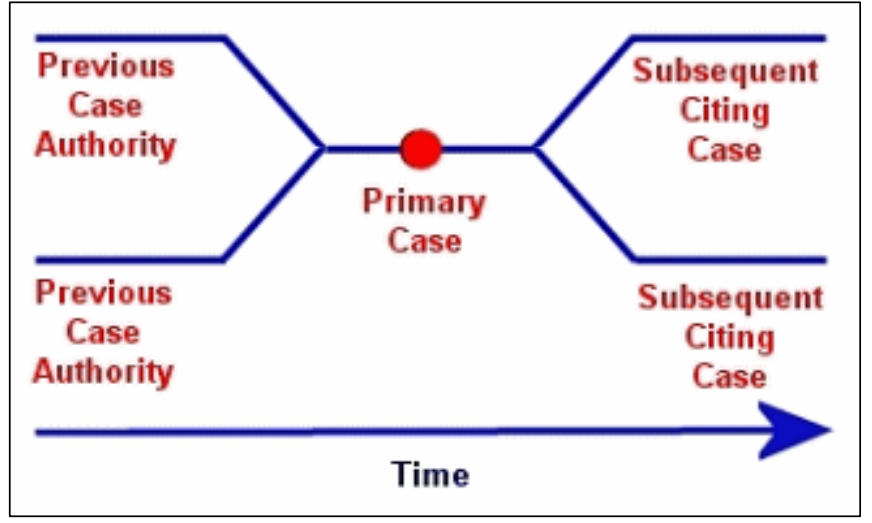

Figure 9-The Stream of Precedent of precedent that the original case is built upon is also good law. The higher level concept for students is that cases exist in a stream of precedent through time, and this stream has to be checked and understood, rather than a single case. Finally, it is worth emphasizing the role that citators and annotations can play in determining the status of statutes, such as the California statute providing exemption from creditors. ${ }^{35}$

\section{Understanding}

As a tax attorney, one of the important lessons I had to learn is that finding and reading the relevant statute usually did not lead to immediate understanding or resolution of the problem. Moreover, I usually found it difficult to place the statute into context. What case, regulation, Revenue Ruling, or other code section, perhaps a thousand sections away, might bear upon the statute? I quickly learned to put tax code sections into context and understand them by utilizing

\footnotetext{
${ }^{35}$ Citators and annotations are organized by citation (using a combination of subject, jurisdiction, and
} chronological arrangements) and are located in the third column of Table 4, as a category separate from topical or chronological arrangements of law. As such, they are not included as a dimension in the Octant schema. It should be noted that Lexis' Shepard's and West's KeyCite are distinguishable on the basis of intermediation. The former is human intermediated, and the latter depends upon computer algorithm. 
the CCH Standard Federal Tax Reporter, ${ }^{36}$ a combined resource that includes the US tax code, its legislative history, implementing regulations, analysis and commentary (known as “CCH explanations”), and indexed annotations. By linking the code to commentary, I was able to find my way to an understanding of the code, issues involved, and resolution of my research problem.

The lesson I learned with the tax code applies to almost any primary material. How does a researcher make sure that his or her understanding of a particular case, code section, regulation or statute comports with that of other attorneys and judges? For California, the researcher could look up the applicable case, In Re Stern, ${ }^{37}$ in the "Table of Cases” for California Jurisprudence, and see what, if anything, has been said by commentators about it. Likewise, the researcher can look up California Code of Civil Procedure § 704.115 in the “Table of Statutes.”38 Similar research can be done for federal cases in American Jurisprudence or Corpus Juris Secundum. If the case is cited or, better yet, annotated in American Law Reports, there may be a wealth of information leading to understanding the case. If the case is annotated, a researcher would be foolish to ignore what $A L R$ has to say about the case (since it is a collection of "slices of the law,” based upon most-representative cases). Using citation analysis with Lexis and Westlaw,

\footnotetext{
${ }^{36}$ As a combined resource, CCH’s Standard Federal Tax Reporter, falls both into the primary, subject,
} controlled vocabulary octant for its arrangement of the tax code, regulations, and annotations of citing cases and IRS rulings (codes, regulations and annotations follow topical arrangements), and the secondary, subject, controlled vocabulary octant for its CCH Explanations, which are written by editors.

${ }^{37}$ Gill v. Stern (In re Stern), 345 F.3d 1036 (9th Cir. 2003), cert denied, Stern v. Gill, 541 U.S. 936 (U.S. 2004).

${ }^{38}$ Enforcement of Judgments, 30 CAL. JUR. § 294 (3rd ed. 2000-) (discussion of exemptions for private retirement plans in CAL CIV. PROC. CODE § 704.115). 
law reviews, treatises, and other materials can be quickly located to help with understanding statutes, regulations, cases, constitutions, and other primary sources.

\section{Conclusion}

Experts think differently than novices. By using schemata, they can see patterns and rapidly organize information and problems to reach resolutions. This paper has presented a complex problem and a series of schemata necessary for its resolution as an example of one approach to legal research and analysis. These schemata appeared in three major parts—-those designed to help work or see the problem, those dedicated to understanding the terrain of legal resources, and those matching resources to problem types and outlining the legal research process.

The schemata in this article are not meant to be the "be all and end all" of legal research. Rather they should challenge legal research instructors and librarians to make explicit their own implicit schemata. Hopefully, my colleagues will refine my schemata and introduce their own to the profession. For instance, schemata for institutional, statistical, special, news, and reference searches have not been explored in this article. ${ }^{39}$ Ideally, our students will not only adopt and master such schemata for problem solving, but they will also learn to assess and adapt them as needed.

Much of legal academia does not view legal research instruction as anything but training in a mechanical exercise. At a recent faculty meeting dedicated to curriculum reform, a colleague of mine propounded that legal research lacked critical reasoning skills and therefore had lesser priority. Hopefully, this article illustrates that legal research is anything but a

\footnotetext{
${ }^{39}$ See supra Table 2.
} 
mechanical, rote exercise. It requires critical thinking and creativity, including the application of abstract concepts and systems to concrete, complex problems.

I hope the progression of schemata also suggests the possibility of a common hierarchical taxonomy of skills, a Bloom's Taxonomy, ${ }^{40}$ to help establish a common vocabulary, define problem-solving skills more precisely, provide a general order for their introduction to students, and set down benchmarks for the improvement and assessment of research skills. Such a project might go a long way toward improving the standing of legal research in the law school curriculum, but it is a project far beyond the scope of this paper, and any one librarian. It must be embarked upon by law librarians and research instructors as a collective, organized effort, perhaps under the auspices of AALL.

In criticizing the absence of any discussion of legal research in the Carnegie Foundation's 2007 report on legal education, Richard Leiter notes: “The absence of focused treatment of legal research in the modern debate about reform of legal education happens because we don't have an accurate vocabulary and virtually no research of our own to give form to the discussion.»"41 Vocabulary is an initial step in creating a Bloom's taxonomy. It is part and parcel of constructing the schemata that expert researchers use to solve problems. Arranging vocabulary

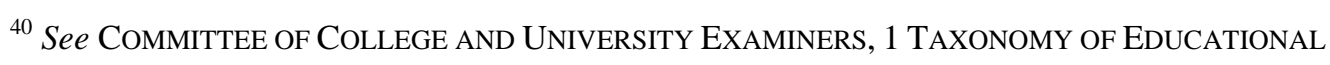
OBJECTIVEs: Cognitive Domain 201-07 (Benjamin S. Bloom ed., 31st prtg., 1987).

${ }^{41}$ Richard A. Leiter, The Missing Lawyering Skill, A New Book on Legal Education Demonstrates the Lack of Attention Paid to Legal Research Training, AALL SPECTRUM, July 2008, at 22, 25. See also, WilliAm M. Sullivan, ET AL., CARNEgIE Foundation FOR THE AdVANCEMENT OF TEACHING, EdUCATING LAWYERS: Preparation For the Practice Of LAW (2007) (as Leiter has pointed out, note the lack of any reference to "legal research," "library," or "research” in the index). 
and schemata into a hierarchical taxonomy that defines the progression of necessary cognitive skills is the ultimate objective. Such taxonomy would establish a credible pedagogy, help communicate the indispensible role of legal research instruction in curriculum reform, and most importantly, improve the research skills of the legal profession.

In closing, my plea is that my colleagues take up the challenge of grounding legal research instruction in a common taxonomy of interrelated schemata, technical vocabulary, and progression of cognitive skills. The failure to have done so suggests that we do not take our own field seriously, and if we do not, why should we expect colleagues from other fields to do so? Indeed, this omission may have kept legal research instruction off of the radar of the elite pedagogues already laboring mightily in the cause of legal education reform. At this critical juncture, we must make the effort to add rigor to our pedagogy by finally defining it. Our students and law faculty colleagues do not "first see, and then define." We must first define, and then they will see. ${ }^{42}$

\footnotetext{
${ }^{42}$ See LipPMANN, supra note 1.
} 